\title{
Detecting human mobility in the Pyrenees through the analysis of chert tools during the Upper Palaeolithic
}

\author{
Marta Sánchez de la Torre \\ Seminari d'Estudis i Recerques Prehistòriques, Dept. Prehistòria, Història Antiga i Arqueologia, Universitat de \\ Barcelona, Spain. Email: martasanchezdelatorre@ub.edu
}

\begin{abstract}
:
The purpose of this paper is to present the preliminary results of $\mathrm{PhD}$ research focused on huntergatherer groups that occupied the Central and Eastern Pyrenees during the Magdalenian period. This research aims to improve the knowledge we have about those Magdalenian groups, specifically concerning their lithic procurement strategies. The core of the study is based on the lithic tools collected from two archaeological sites - Alonsé Cave and Forcas I Shelter, both in Huesca, Spain, and in particular those made from chert, because they are both a spatial and a cultural marker at the same time. These cherts have been studied using petroarchaeological methods, and as a result, it has been possible to detect the type of procurement strategies carried out and to guess the relation existing between those human groups and their environment, especially in what refers to mobility strategies.
\end{abstract}

Keywords: petroarchaeology, Alonsé Cave, Forcas I Shelter, Cantabrian Lower Magdalenian

\section{Résumé:}

L'objectif de cet article est de présenter les premiers résultats d'une thèse de doctorat qui concerne les groupes de chasseurs-cueilleurs qui ont occupé les Pyrénées centrales et orientales pendant le Magdalénien. Le but de cette recherche est d'améliorer la connaissance qu'on a de ces groupes magdaléniens, justement en ce qui concerne les stratégies d'approvisionnement lithique. La base de l'étude est les outils lithiques récoltés dans deux sites archéologiques - la Grotte Alonsé et l'Abri de Forcas I (tous les deux situés à Huesca, Espagne), en particulier les artefacts en silex, parce qu'ils sont à la fois un marqueur spatial et culturel. Ces silex ont été étudiés selon la méthode archéopétrologique et, comme résultat, il a été possible détecter les stratégies d'approvisionnement menées. Cette étude a aussi permis d'apporter de nouvelles données sur la relation existant entre ces groupes humains et leur environnement, en particulier en ce qui concerne leurs stratégies de mobilité.

Mots clés: archéopétrologie; Grotte Alonsé; Abri de Forcas I; Magdalénien inférieur cantabrique

Published by the School of History, Classics and Archaeology, University of Edinburgh ISSN: 2055-0472. URL: http://journals.ed.ac.uk/lithicstudies/

This work is licensed under a Creative Commons Attribution 2.5 UK: Scotland License. 


\section{Resumen:}

El objetivo de este artículo es presentar los primeros resultados de una tesis doctoral que versa sobre los grupos de cazadores-recolectores que ocuparon el Pirineo central y oriental durante el Magdaleniense. El objetivo de esta investigación es mejorar el conocimiento que a día de hoy se posee sobre dichos grupos magdalenienses, precisamente en lo referido a las estrategias de aprovisionamiento lítico. La base del estudio son los restos líticos recuperados en dos yacimientos arqueológicos - Cova Alonsé y Abrigo de las Forcas I (ambos en la provincia de Huesca, España), y en particular los artefactos en sílex, pues constituyen un marcador a la vez espacial y cultural. Dichos artefactos han sido estudiados según el método arqueopetrológico y, como resultado, ha sido posible detectar el tipo de estrategias de aprovisionamiento llevadas a cabo. Este estudio también ha permitido aportar nuevos datos sobre la relación existente entre los grupos humanos y su entorno, en particular en lo concerniente a las estrategias de movilidad.

Palabras clave: arqueopetrología; Cova Alonsé; Abrigo de Forcas I; Magdaleniense inferior cantábrico

\section{Introduction}

The study of the materials recovered from an archaeological site is essential to learning more about the human groups that generated those remains, as they provide valuable data for the economic, social and symbolic functioning of a community. When the site studied belongs to the Palaeolithic period, in which human remains are usually limited to begin with and damaged by the passage of time, recovered materials are the only documentary evidence to approach the reality of these groups.

Lithic raw materials are therefore fundamental elements to delve into the behaviour of Palaeolithic humans, and a study from a multidisciplinary approach is essential to gathering as much information as possible. Considering that stone tools are spatial and cultural markers, their analysis by petroarchaeological methods will provide information on the origin of these materials and the mobility of a group, as well as the possible existence of natural or artificial borders to a society.

The research area of this study is an ideallocation for the analysis of lithic raw materials. Until now, petroarchaeological studies on the southern slopes of the Pyrenees have focused on the Eastern Pyrenees where interesting works have been developed over the last two decades (Terradas 1996, Mangado 2005 and Ortega 2002), and in Western Pyrenees (Tarriño 2006). On the north side of this mountain range, the analysis of lithic raw materials began much earlier, the most recent studies being those by S. Gregoire (2000) and F. Briois (1997) in Eastern Pyrenees, R. Simonnet (1999), P. Foucher (2004) and S. Lacombe (1998) in Central Pyrenees and C. Normand (2002) in Western Pyrenees.

Nevertheless, the central area of the southern slope of the Pyrenees, despite being an areawith important Palaeolithic sites long known and excavated with a modern methodology, has employed limited petroarchaeological studies until now. Therefore, the aim of this paper is to present the preliminary results obtained after petroarchaeological study of two Palaeolithic sites located in the central Pyrenean foothills: Alonsé Cave and Forcas I Shelter. Both sites have similar chronology levels attributed to the Upper Palaeolithic (Cantabrian Lower Magdalenian) and are at a distance of $10 \mathrm{~km}$ from each other. For this reason the similarities and the differences observed after the research was carried out are emphasized, in order to guess the type of the resource strategies employed. 


\section{Methodology}

To accomplish the research objectives, petroarchaeological methods were applied. These methods use descriptions and classifications from the natural sciences, such as petrology, to characterise, define and name rocks used by past societies. Initially a system of petroarchaeological characterisation of lithic tools recovered from two archaeological sites was developed. This characterization was done in terms of two scales of analyses. First, a macroscopic examination of the entire set was carried out using a binocular microscope, an Olympus SZ61 model (from 6.7 to $45 \mathrm{x}$ ) and a supplementary light source, depending on the samples (Cold Light transmitted Olympus TH4-200 model). Snapshots were taken with a coupled Olympus SC20 model camera.

Afterwards, a petrographic and micropaleontological characterization of those materials was performed by analysing them in thin sections. A total of 35 thin sections were made from geological and archaeological samples. These thin sections, with thicknesses between 25 and $30 \mu \mathrm{m}$, were created at the Servei de Làmina Prima laboratory of the University of Barcelona, and were analysed using a petrographic Olympus BX41 model microscope (from 40 to $400 \mathrm{x}$ magnification).

At the same time that the archaeological materials were being studied, fieldwork was carried out to localize chert outcrops that could have been used as a procurement place for the hunter-gatherers that occupied Alonsé Cave and Forcas I Shelter. As a result, cherts outcrops were found from five geological formations in a radius of $50 \mathrm{~km}$ around the archaeological sites. Subsequently, the geological samples were compared with the archaeological samples, both macroscopically and petrographically.

The results obtained so far are not yet definitive, but in any case they represent a first approach to hunter-gatherer lithic procurement strategies that were employed in the central Pyrenees during the Cantabrian Lower Magdalenian.

\section{Geological features of the upper and the middle Cinca River Basin}

\subsection{The Geographical and geological area of study}

The research area is located in Western Europe, specifically in the northeast of the Iberian Peninsula. This area presents a large mosaic of different geological and ecological environments, associated with the existence of three major geographical units: the Pyrenees, the Central Depression and the Mediterranean system (Figure 1).

The archaeological sites studied are located in the contact zone between the Pyrenees and the Central Depression, in an area known as the Pyrenean foothills. These mountain elevations present a step relief with elevations that exceed $1000 \mathrm{~m}$ above sea level. The formation of this mountain range dates back to the late Cretaceous, when the Iberian and Eurasian shelves collided. This collision caused the compression and elevation of the huge amounts of sediments that had been deposited in the Pyrenees. As a result, the current reliefs of the Pyrenees rose. Two of these mountain elevations that were moved to the south are the Carrodilla mountain range and the Llaguarres Castle mountain range, close to which are located Alonsé Cave and Forcas I Shelter.

The Llaguarres Castle mountain range is made up of conglomerates with some calcareous outcrops from the end of the second range. The Carrodilla mountain range presents Triassic formations of limestones and clays from the Muschelkalk and the Keyper period. Limestones and marls represent the Cretaceous, and finally, fossiliferous limestones from the Eocene constitute the Cenozoic series (Vera, 2004). 


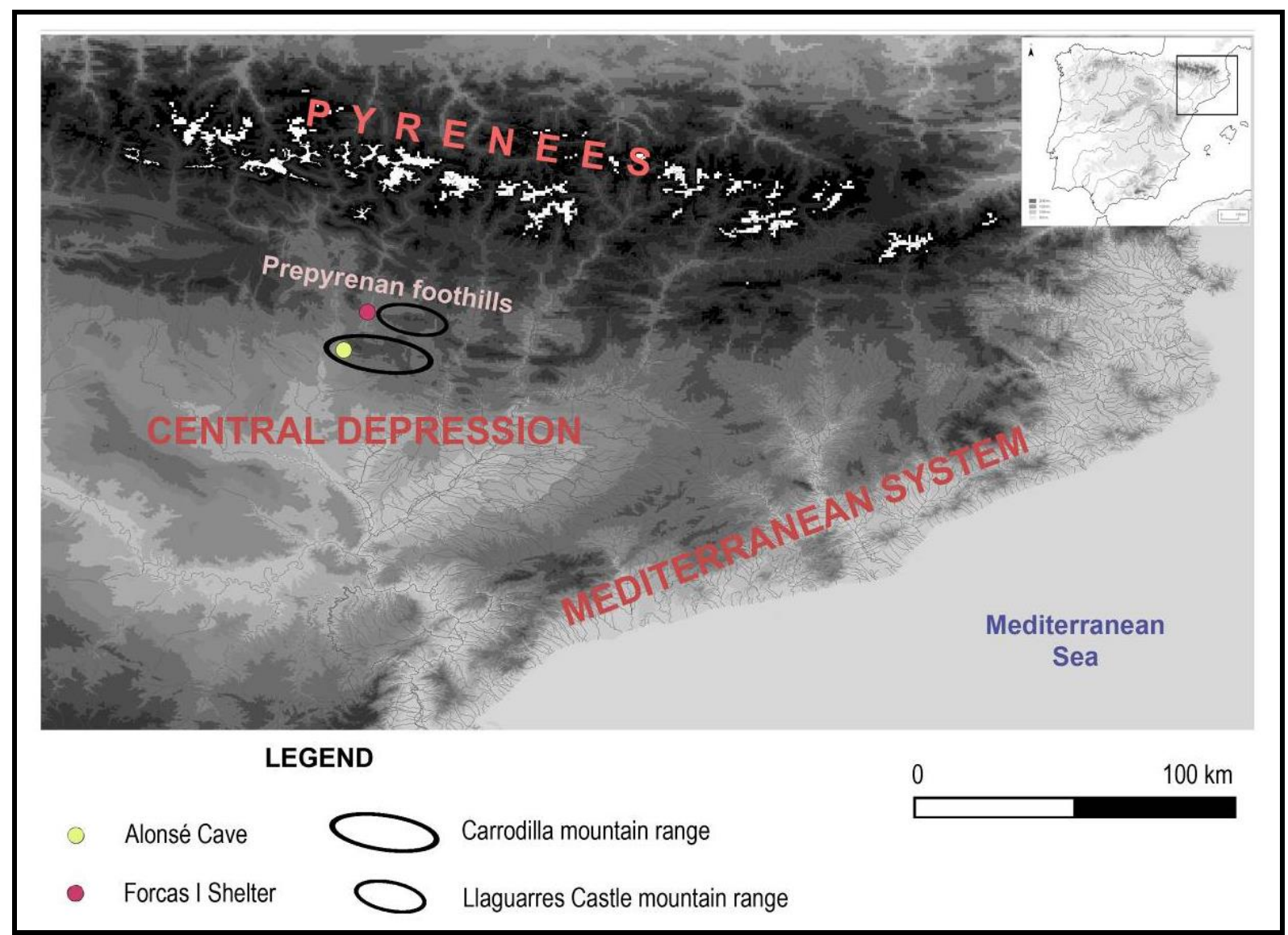

Figure 1. Study area with the main geographical units of the region and the location of the two archaeological sites.

The Pyrenean foothills are crossed from north to south by a large river basin that collects water from the Pyrenees and distributes it to the Mediterranean Sea via the Central Depression. The Cinca River is one of those axes which, in the Central Pyrenees, flow into de Ebro River basin. The Isábena and the Ésera rivers are two tributaries of the Cinca River (Figure 2).

\subsection{Geological formations with chert-bearing outcrops detected}

After carrying out various field trips, six geological formations that contained cherts in primary position in an area of $50 \mathrm{~km}$ around the archaeological sites were finally detected. Below are brief petrological descriptions of the cherts and their sedimentary matrix, as well as their original paleogeographical context of origin (table 1) (Figures 2 and 3).

A. Cherts from the Castelltallat formation (Rupelian, Oligocene)

This formation, which is composed of micritic limestones with Charophyte algae, ostracods, gastropods and chert nodules, outcrops between the Ebro basin and the Pyrenean foothills, along the Serra Llarga, where more than forty points of chert outcrops were detected (Mangado 2005). The same formation emerges nearest to the archaeological sites, near Peraltilla (Huesca) (Sáez 1987).

These cherts have a heterogeneous texture with plenty of inclusions: metal oxides, grains of detrital quartz and micritic residues. Transverse and longitudinal sections of Charophyte algae are frequent, as well as lacustrine gastropods. These cherts originated in a lacustrine sedimentary environment. 


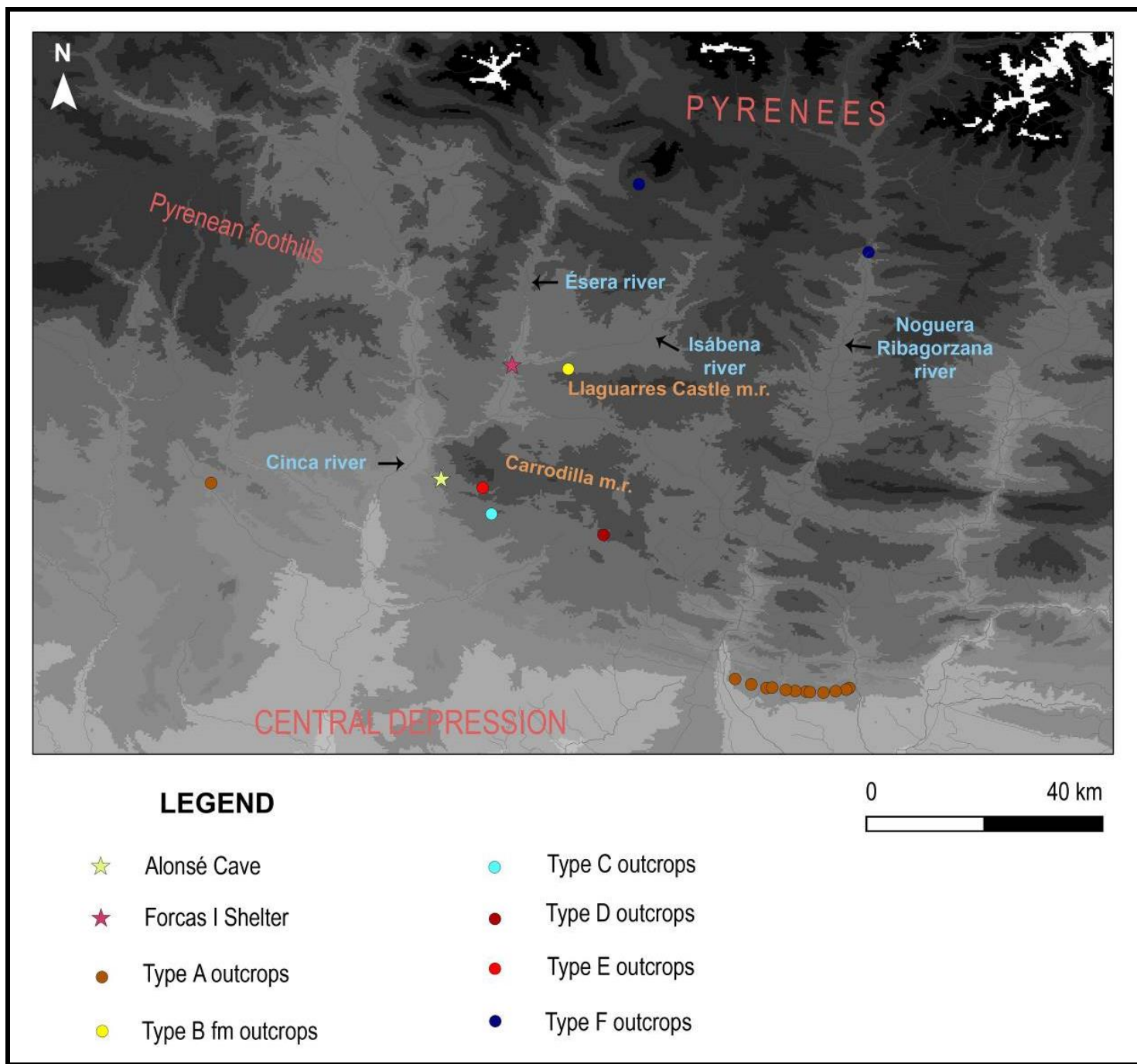

Figure 2. Location of the different geological formations with chert outcrops detected in the region.

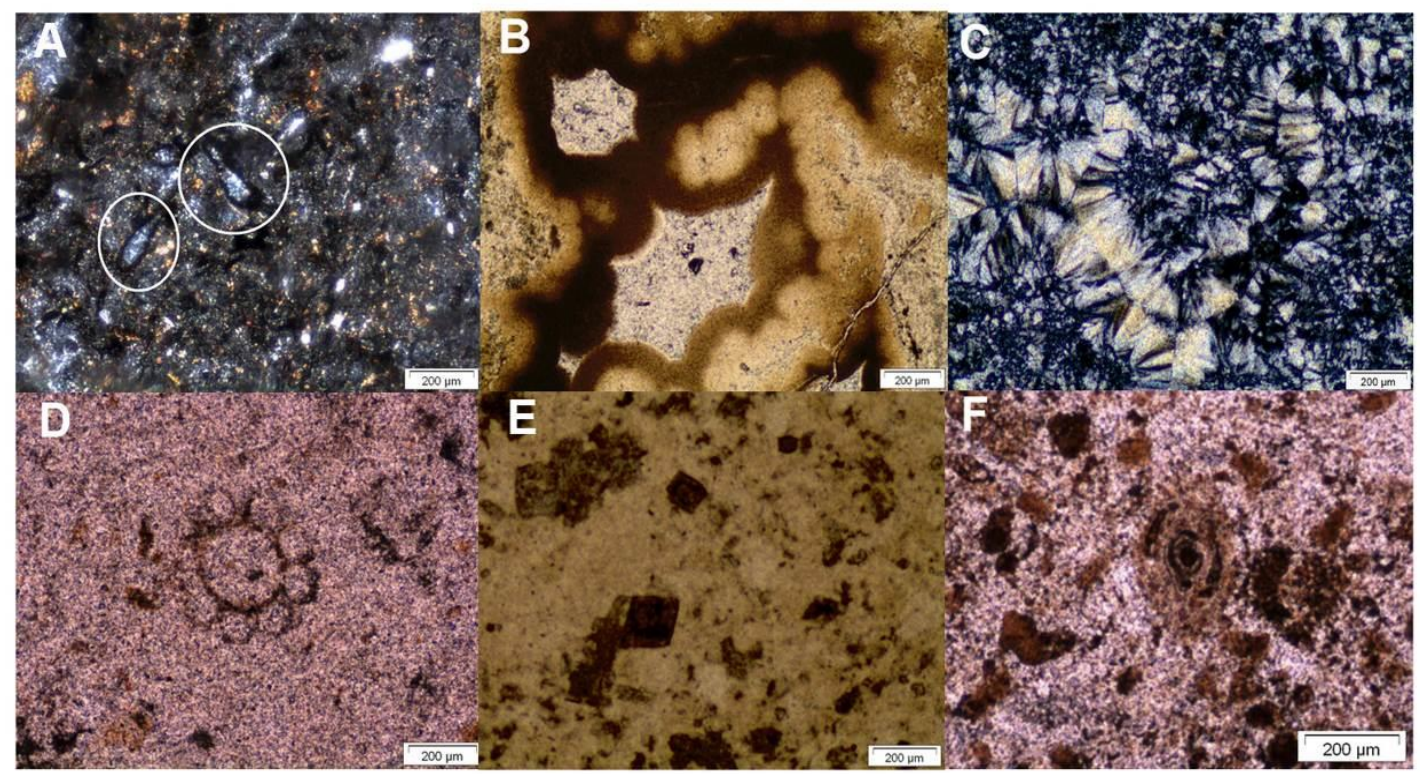

Figure 3. Microscopic view of each group. A. and D. Charophyte algae; B. Opal and carbonates; C. Microquartz and chalcedony; E. Rhombohedral dolomite crystals; and F. Miliolida. Images A and C are crossed polariser views, while the rest are seen in single polariser view. See below for further descriptions. 
On a microscopic scale, the primary silica texture is a microquartz mosaic (52\%) and, in some cases, length-fast chalcedony appears (3\%). Carbonate components are abundant (37\%) and in low proportions metal oxides (2\%) and sub-angular detrital quartz (3\%) are observed. Samples also have up to $3 \%$ porosity.

\section{B. Cherts from the Puy de Cinca formation (Paleogene)}

This formation has two levels with silicifications, one possibly ascribed to a continental hypersaline environment and another that could have originated in a marine sedimentary environment (Menéndez et al. 2009). Outcrops are known of in the Llaguarres Castle mountain range.

Macroscopically, these cherts exhibit inclusions of metal oxides, micritic residues and lenticular gypsum pseudomorphs. Some bioclasts have been identified (possibly foraminifera). On a microscopic scale, a mosaic microquartz is the main texture (57\%). Other silica forms are represented: length-fast chalcedony (3\%), opal (3\%) and macroquartz (2\%). Carbonate components are abundant $(29 \%)$ and in very low percentages metal oxides appear $(1 \%)$. Finally, the presence of porosity (5\%) needs to be highlighted.

\section{Cherts from the Garumnian Facies (Maastrichtian, Upper Cretaceous)}

In the Garumnian limestones of the Pyrenean foothills there are outcrop of cherts which originated in a continental hypersaline environment. Different chert outcrops were identified in the Carrodilla and Montsec mountain ranges. As well, in the Carrodilla mountain range a primary deposit of chert that also contained the abundant remains of chert knapping activity was identified.

The suitability of these nodular cherts for knapping varies depending on the individual nodule. Macroscopically, these cherts present metal oxides and lenticular gypsum pseudomorph inclusions. No bioclastic elements have been identified. In some cases there are cracks, often filled by macroquartz crystals. By petrographic microscope, a mosaic of microquartz as the main texture can be observed (76\%). Other silica forms are present filling old pores: length-slow chalcedony (8\%), length-fast chalcedony (4\%) and macroquartz (8\%). Non-silica components are scarce, only micritic residues (4\%) having been observed.

\section{Cherts from the Tremp formation (Maastrichtian, Upper Cretaceous)}

A level of well laminated micritic limestones with Charophyte algae and gastropods moulds filled with sparite were documented in the Tremp formation. This package also contained nodular chert levels. These cherts outcrop in the Pyrenean foothills, specifically in the Montsec and the Carrodilla mountain ranges, where several outcrops have been located.

Macroscopically, these cherts present a heterogeneous texture with impurities of mineral oxides (hematite grains), micritic residues, organic amorphous material and macroquartz filling pores. Charophyte algae and, in lower proportions, gastropods and ostracods form the bioclastic content.

On a microscopic scale, a microquartz mosaic is the main texture (78\%). Length-fast chalcedony (4\%) has been identified filling pores and macroquartz is poorly represented (1\%). Carbonate components add up to $15 \%$ (micritic residues and some bioclastic elements that have not yet been silicified). Iron oxides are present as $2 \%$ and sub-angular detrital quartz rarely appears. 
E. Cherts from the Campanian - Maastrichtian (Campanian - Maastrichtian, Upper Cretaceous)

In the Carrodilla mountain range, next to the Maastrichtian limestones with chert, appears a micritic limestone formation from the Campanian - Maastrichtian that includes nodular cherts. This lithofacies are associated with a carbonate-lacustrine environment progressively confined to marsh sub-environments (Sáez 1987).

Macroscopically, these cherts exhibit high potential for knapping and present a heterogeneous texture with metal oxides and micritic residues as impurities. Charophyte algae and Miliolidae represent the main micropalaeontological content.

F. Cherts from the Agua-Salenz formation (Conacian, Upper Cretaceous) and Pardina formation (Cenomanian - Turonian, Upper Cretaceous)

The Agua-Salenz formation and its lateral equivalent, the Pardina formation, present laminated limestones with sponge spicules and abundant nodular cherts formed in a slope and basin environment. Chert outcrops are located in the south of the Pyrenees, near the Turbón massif (Agua-Salenz formation) and the Sopeira basin (Pardina formation). In one of the outcrops identified in the Turbón massif, abundant remains of chert knapping activity were found.

These nodular cherts possess high potential for knapping. Their textures are heterogeneous with many impurities of metal oxides, detrital quartz, rhombohedral calcite or dolomite crystals, micritic residues and probably organic material. The bioclastic content is comprised of Porifera and small foraminifers .

Microscopically, a microquartz mosaic is identified as the main texture $(75 \%)$ and the only silica component. Carbonate elements are abundant $(22 \%)$ and in a very low proportion iron oxides $(1 \%)$ and detrital quartz crystals $(2 \%)$ are present.

The main characteristics observed after the examination of the different types of chert that outcrop near the studied sites are briefly identified in table 1. Thus, one of the types identified (F) has many very special characteristics and can easily be identified by macroscopic observation. Type $\mathrm{C}$, originating from a hypersaline environment, has some similarities with group $\mathrm{B}$, but type $\mathrm{C}$ cherts have special characteristics which allow them to be differentiated them from type $\mathrm{B}$ cherts.

More problematic is the macroscopic or microscopic distinction of cherts from types A and $\mathrm{D}$, because the only element that seems to be different between both cherts is the level of carbonate elements, which are most abundant in cherts from group A. Transitional cherts from type E, despite sharing many features with the previous groups, present a special micropalaeontological content formed by the presence of Charophyte algae and Miliolidae, which is not observed in the other types.

\section{The petroarchaeological study of Alonsé Cave: results}

\subsection{The archaeological site}

Alonsé Cave is a small cave located in the eastern province of Huesca, in the river Cinca axis. It is located in the Carrodilla mountain range, stretching from east to west, and becoming the first Pyrenean foothills in the area. Due to erosive processes and recent human activities in the area only one archaeological level has been preserved. It was excavated over two field seasons by a team from the University of Zaragoza, led by Dr. Lourdes Montes and Dr. Rafael Domingo (Montes \& Domingo 2013).

The typology of the materials recovered allowed the researchers to ascribe the archaeological level to the Cantabrian Lower Magdalenian. This chronology was confirmed 
by two radiocarbon dates (uncalibrated) obtained at the University of Groningen: $14840 \pm 90$ BP (GrA-21536) and $15069 \pm 90$ BP (GrA-21537) (Montes \& Utrilla 2008).

Table 1 - Main characteristics of cherts identified during fieldwork. Abbreviations: Hi - high; Me - medium; C continental; $\mathrm{T}$ - transitional; $\mathrm{M}$ - marine.

\begin{tabular}{|c|c|c|c|c|c|c|c|c|c|c|c|c|c|c|c|c|c|c|c|}
\hline \multirow[b]{2}{*}{ 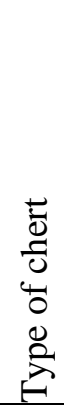 } & \multirow[b]{2}{*}{ 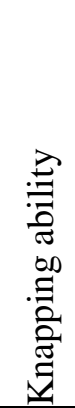 } & \multicolumn{12}{|c|}{ Macro. characteristics } & \multicolumn{5}{|c|}{$\begin{array}{l}\text { Micro. characteristics } \\
\text { (siliceous components) }\end{array}$} & 离 \\
\hline & & $\begin{array}{l}\frac{\tilde{v}}{0} \\
\frac{\Delta}{0} \\
\frac{\pi}{\pi} \\
\sum^{0}\end{array}$ & 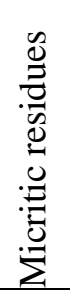 & 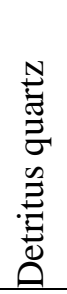 & 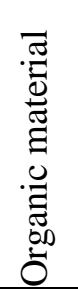 & 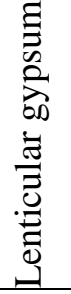 & 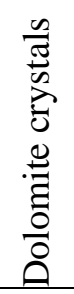 & 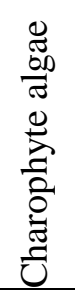 & 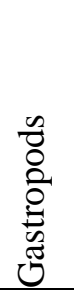 & 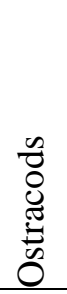 & 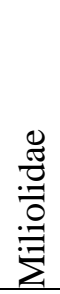 & 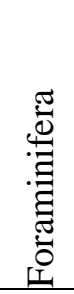 & $\begin{array}{l}\frac{0}{3} \\
\frac{0}{3} \\
0 \\
0 \\
0 \\
0 \\
0 \\
0 \\
0 \\
0\end{array}$ & 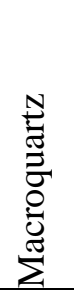 & 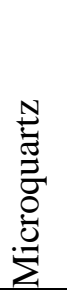 & $\begin{array}{l}\overrightarrow{0} \\
\stackrel{0}{0} \\
\frac{0}{\tilde{J}} \\
\overrightarrow{0} \\
+\end{array}$ & 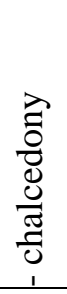 & مَّ. & 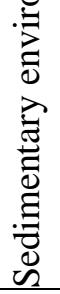 \\
\hline $\mathrm{A}$ & $\mathrm{Hi}$ & $\mathrm{x}$ & $\mathrm{X}$ & $\mathrm{X}$ & & & & $\mathrm{X}$ & $\mathrm{X}$ & & & & & & $\mathrm{x}$ & & $\mathrm{x}$ & & $\mathrm{C}$ \\
\hline B & $\mathrm{Me}$ & $\mathrm{x}$ & $\mathrm{x}$ & & & $\mathrm{X}$ & & & & & & $\mathrm{x}$ ? & & $\mathrm{X}$ & $\mathrm{x}$ & & $\mathrm{x}$ & $\mathrm{X}$ & $\mathrm{T}$ \\
\hline $\mathrm{C}$ & $\mathrm{Me}$ & $\mathrm{x}$ & & & & $\mathrm{x}$ & & & & & & & & $\mathrm{x}$ & $\mathrm{x}$ & $\mathrm{x}$ & $\mathrm{x}$ & & $\mathrm{C}$ \\
\hline D & $\mathrm{Hi}$ & $x$ & $\mathrm{X}$ & & $x$ & & & $x$ & $\mathrm{x}$ & $\mathrm{x}$ & & & & $\mathrm{X}$ & $\mathrm{x}$ & & $\mathrm{x}$ & & $\mathrm{C}$ \\
\hline $\mathrm{E}$ & $\mathrm{Hi}$ & $\mathrm{x}$ & $\mathrm{x}$ & & & & & $\mathrm{x}$ & & & $\mathrm{X}$ & & & & & & & & $\mathrm{T}$ \\
\hline $\mathrm{F}$ & $\mathrm{Hi}$ & $\mathrm{x}$ & $\mathrm{x}$ & $\mathrm{X}$ & $\mathrm{X}$ & & $\mathrm{X}$ & & & & & $\mathrm{x}$ & $\mathrm{x}$ & $\mathrm{X}$ & & & & & $\mathrm{M}$ \\
\hline
\end{tabular}

\subsection{Types of cherts identified}

The assemblage recovered at the archaeological site of Alonsé Cave was composed of about 4058 lithic elements, from which a total of 3963 pieces $(97.61 \%)$ were on chert. The characterisation, which recently has been published extensively (Sánchez \& Mangado 2013), allowed us to identify two main groups of cherts with different features (Table 2, Figure 4).

\section{TYPE 1}

This is the main group, representing $91.72 \%$ of the assemblage. With high knapping potential, these cherts present a heterogeneous texture. Macroscopically, metal oxides, micritic residues, grains of detrital quartz and probably also organic material were observed. Charophyte algae and gastropods represent the micropaleontological content. These cherts originated in a lacustrine sedimentary environment.

At the petrographic level, microquartz mosaic constitutes the main texture in the samples $(62-88 \%)$. Other silica forms are present in low proportions, basically as pore filling: lengthfast chalcedony and macroquartz (2-5\%). Carbonate elements vary depending on the sample (5-28\%) and metal oxides and terrigenous components are poorly represented.

\section{TYPE 2}

This second group comprises $7 \%$ of the archaeological assemblage. They are cherts with variable potential for knapping. Macroscopically, they are characterised by the absence of bioclastic content, as they originated in a hypersaline sedimentation environment. Texture is quite smooth and only a few inclusions of metal oxides and lenticular gypsum pseudomorphs were identified.

Microscopically, microquartz is the main texture (83\%). Length-fast chalcedony, lengthslow chalcedony and macroquartz are also present, but in lower proportions (5\%). Carbonates are testimonial and metal oxides and evaporitic evidences are abundant (12\%). 
Table 2 - Main characteristics of each type of chert identified. Abbreviations: Hi - high; M medium; CL - continental (lacustrine); $\mathrm{CH}$ - Continental (hypersaline); T - transitional.

\begin{tabular}{|c|c|c|c|c|c|c|c|c|c|c|c|c|c|c|c|c|}
\hline \multirow[b]{2}{*}{$\begin{array}{l}\frac{\pi}{0} \\
\frac{0}{0} \\
4 \\
0 \\
0 \\
0 \\
0 \\
0\end{array}$} & \multirow[b]{2}{*}{ 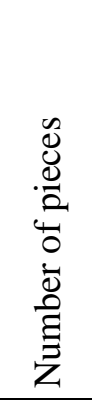 } & \multirow[b]{2}{*}{ 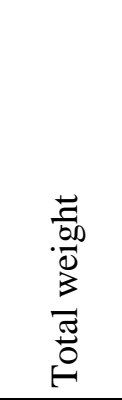 } & \multirow[b]{2}{*}{ 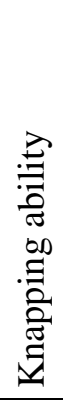 } & \multicolumn{8}{|c|}{ Macro characteristics } & \multicolumn{4}{|c|}{ Micro char. } & \multirow[b]{2}{*}{ 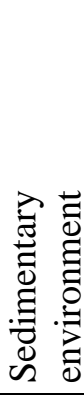 } \\
\hline & & & & 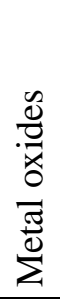 & 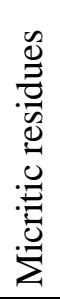 & 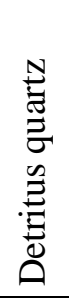 & 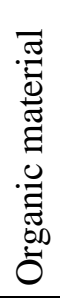 & 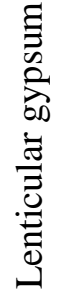 & 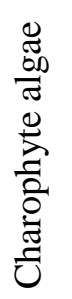 & 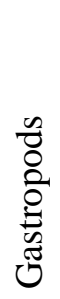 & 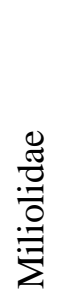 & 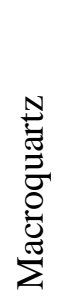 & 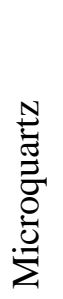 & $\begin{array}{l}\vec{\Xi} \\
\overline{0} \\
\frac{0}{0} \\
\frac{\pi}{\tilde{J}} \\
\frac{0}{0} \\
+\end{array}$ & 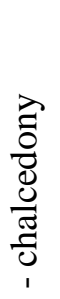 & \\
\hline T.1 & 3635 & $5.482 \mathrm{~g}$ & $\mathrm{Hi}$ & $\mathrm{X}$ & $\mathrm{x}$ & $\mathrm{x}$ & $\mathrm{x}$ & & $\mathrm{x}$ & $\mathrm{x}$ & & $\mathrm{x}$ & $\mathrm{x}$ & & $\mathrm{x}$ & CL \\
\hline T. 2 & 313 & $566 \mathrm{~g}$ & $\mathrm{Me}$ & $\mathrm{X}$ & & & & $\mathrm{x}$ & & & & $\mathrm{x}$ & $\mathrm{X}$ & $\mathrm{x}$ & $\mathrm{x}$ & $\mathrm{CH}$ \\
\hline T. 3 & 5 & $78 \mathrm{~g}$ & $\mathrm{Hi}$ & $\mathrm{x}$ & $\mathrm{x}$ & $\mathrm{x}$ & $\mathrm{x}$ & & $\mathrm{x}$ & & $\mathrm{x}$ & $\mathrm{x}$ & $\mathrm{x}$ & & $\mathrm{x}$ & $\mathrm{T}$ \\
\hline
\end{tabular}

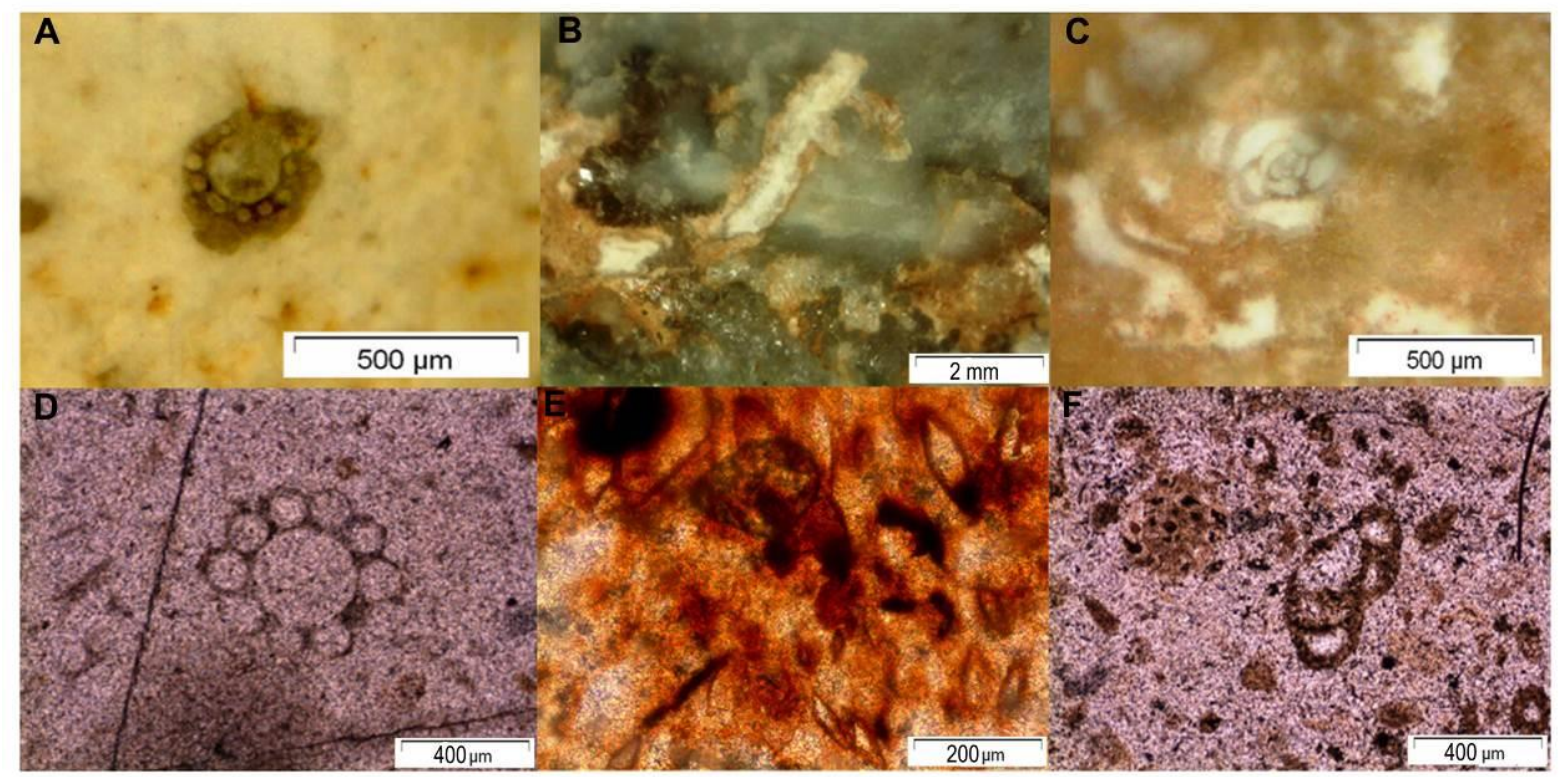

Figure 4. Main characteristics of each group. Type 1 (A and D): Charophyte algae; Type 2 (B and E): B Recrystallizations and E - Lenticular gypsum pseudomorphs; Type 3 (C and F): Miliolidae. Images A to $\mathrm{C}$ are macroscopical view and images D to F are crossed polarised views. See below for further descriptions.

\section{TYPE 3}

A third type of chert was detected, representing less than $0.2 \%$ of the assemblage. Macroscopically they show heterogeneous texture, with inclusions of metal oxides, micritic residues, probably organic material and detritic quartz crystals. The micropalaeontological content is typically related to a transitional sedimentation environment (the presence of Charophyte algae and Miliolidae).

Under the microscope, a microquartz mosaic fabric is the main component (89\%) and in lower proportions other silica forms have been identified: length-fast chalcedony (3\%) and macroquartz (1\%). Among the non-siliceous components, metal oxides are the most abundant (7\%), as the carbonate bioclastic elements are almost entirely silicified. Terrigenous elements seldom appear. 


\subsection{Original formations of the archaeological cherts from Alonsé Cave}

Based on the fieldwork, similarities were found between the archaeological cherts and those that had been located in proximity to the archaeological sitesduring the fieldwork (Figure 5). For the first group, the lacustrine cherts have similarities with the Oligocene micritic limestones located at the contact between the Ebro basin and the Pyrenean foothills, and the lacustrine Maastrichtian limestone levels that outcrop in the eastern area of the Carrodilla mountain range. Both formations have chert outcrops identified within a radius of $30 \mathrm{~km}$ of the site, the closest outcrop (Maastrichtian chert) being located at only $4 \mathrm{~km}$ from the cave. The closest outcrop of the Oligocene chert detected is located at $20 \mathrm{~km}$ from the site.

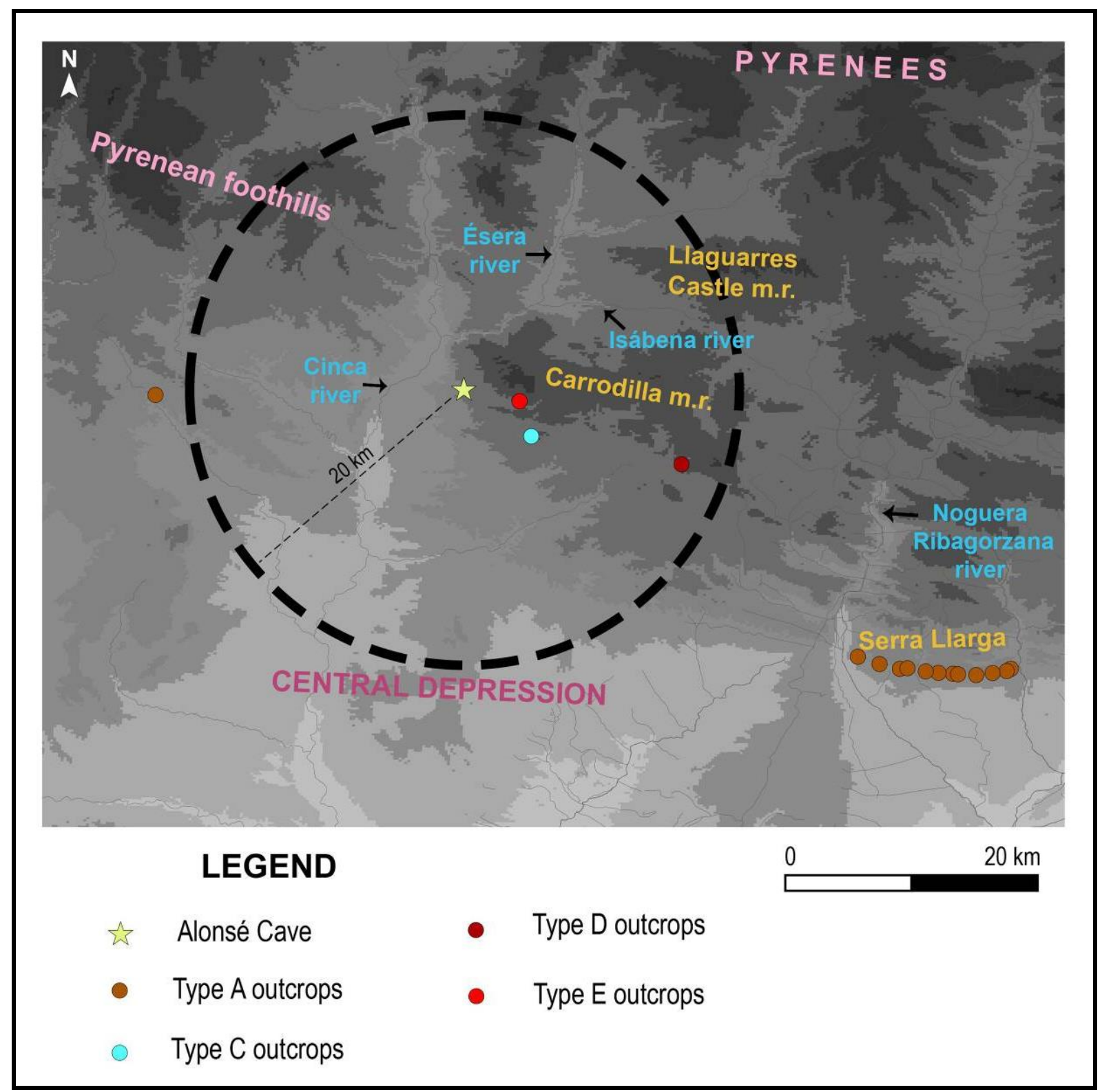

Figure 5. Alonsé Cave and the different geological formations with parallels in the archaeological assemblage.

For the second group of chert, which originated in a hypersaline environment, a chert outcrop was found just $8 \mathrm{~km}$ away from Alonsé Cave, in the Carrodilla mountain range, related to the Garumnian limestone levels. This location also contained abundant remains of chert knapping activity. The similarity between archaeological and geological cherts, the 
proximity to the site, and the evidence of chert knapping lead us to think that Magdalenian hunter-gatherers that occupied Alonsé probably went to this place for provisioning.

The third group, concerning chert with lacustrine and marine characteristics, had parallels with the cherts which originated in Campanian - Maastrichtian limestones that outcrop in the Carrodilla mountain range.

\section{The petroarchaeological study of Forcas I Shelter: results}

\subsection{The archaeological site}

Forcas I Shelter is located in the eastern province of Huesca, near the Ésera river, tributary of the Cinca River. Discovered by chance in 1990, the site was $90 \%$ destroyed due to gravel exploitation in the area. After five field seasons, a team from the University of Zaragoza led by Dr. Pilar Utrilla and Dr. Carlos Mazo excavated and found 14 archaeological levels. The site had been occupied repeatedly, spanning the period of the Cantabrian Lower Magdalenian (14440 \pm 70 uncal. BP), the Late Magdalenian (11015 \pm 45 uncal. BP) and the Early Mesolithic, when the site was occupied between $9715 \pm 140$ uncal. BP and $9360 \pm 75$ uncal. BP (Utrilla \& Mazo 2007).

\subsection{Types of cherts identified}

This is a first approach to the petroarchaeological study of the materials recovered at Forcas I Shelter. Macroscopically, 160 lithic artefacts (tools and remains) from level 15b have been analysed, which are culturally ascribed to the Cantabrian Lower Magdalenian. This sample represents $30 \%$ of the lithic assemblage of this level, which is about 550 lithic pieces. This first characterization allowed for the identification of three different groups of chert, leaving around 3\% of cherts undetermined (table 3) (Figure 6).

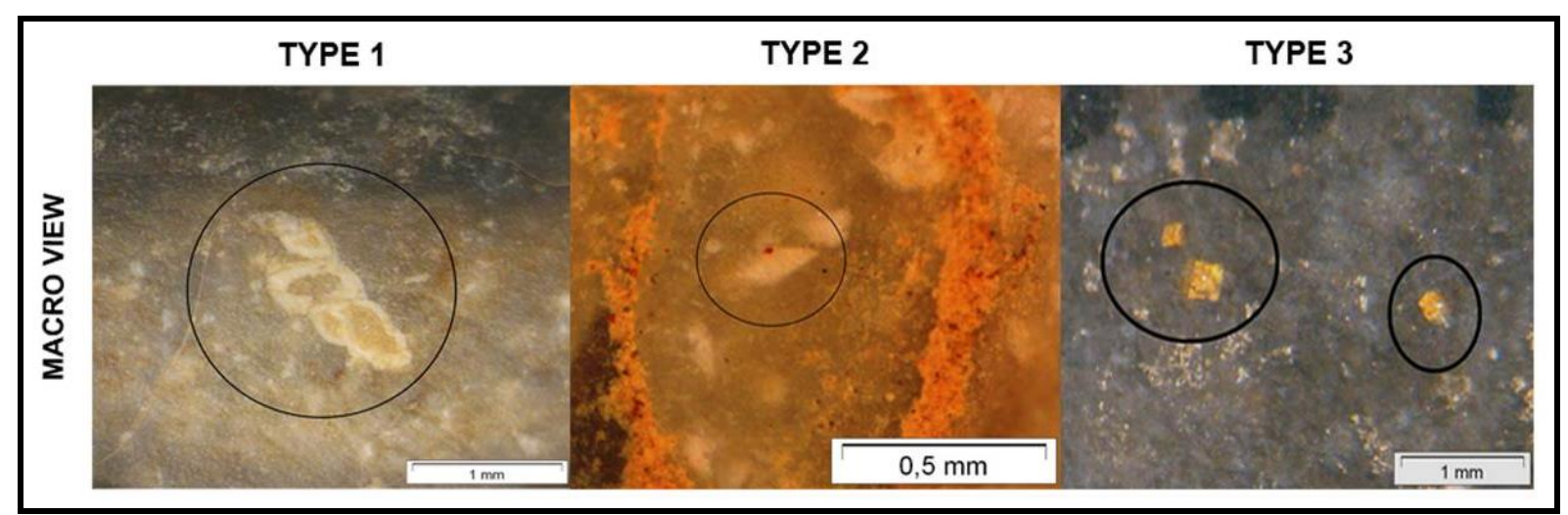

Figure 6. Main characteristics of each group (view from binocular microscope). Type 1: Gastropod section; Type 2: Lenticular gypsum pseudomorph; Type 3: Dolomite crystals.

\section{TYPE 1}

Type 1 represents the main group, corresponding to $67 \%$ of the assemblage. These cherts show a high potential for knapping. Macroscopically a heterogeneous texture is observed, with abundant inclusions of metal oxides, micritic residues and probably organic material. The micropalaeontological content consists of Charophyte algae and gastropods. This type of chert originated in a lacustrine depositional environment. 
Table 3 - Main characteristics of each type of chert identified.

Macro characteristics

\begin{tabular}{|c|c|c|c|c|c|c|c|c|c|c|c|c|c|c|}
\hline 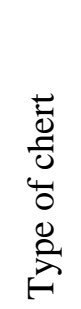 & 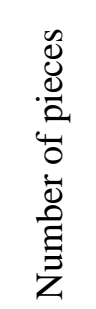 & $\begin{array}{l}\frac{7}{00} \\
\frac{00}{0} \\
3 \\
\frac{\pi}{0} \\
0 \\
0\end{array}$ & 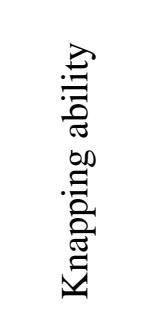 & 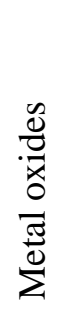 & 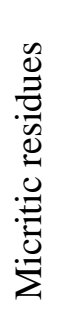 & 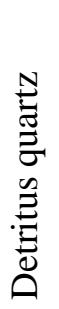 & 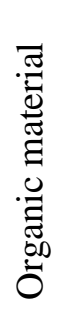 & 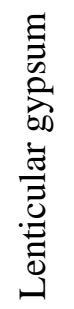 & 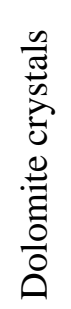 & 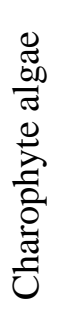 & 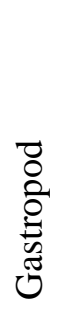 & 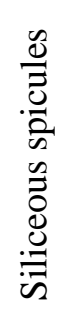 & 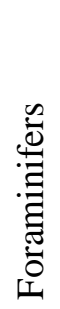 & 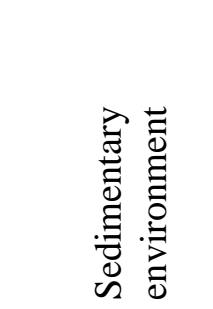 \\
\hline T.1 & 3635 & $5.482 \mathrm{~g}$ & High & $X$ & $X$ & $X$ & $X$ & & & $X$ & $X$ & & & $\begin{array}{l}\text { Continental } \\
\text { (lacustrine) }\end{array}$ \\
\hline T. 2 & 313 & $566 \mathrm{~g}$ & Medium & $X$ & & & & $X$ & & & & & & $\begin{array}{c}\text { Continental } \\
\text { (hypersaline) }\end{array}$ \\
\hline T. 3 & 5 & $78 \mathrm{~g}$ & High & $X$ & & X & $X$ & & $X$ & & & $X$ & & Marine \\
\hline
\end{tabular}

TYPE 2

This second type composes $20 \%$ of the assemblage. There are cherts with varying potential for knapping. Viewed with the binocular microscope, these cherts were characterised by the absence of bioclastic content and the usual absence of impurities, some pieces being completely translucent. When some inclusions were present, they were metal oxides and lenticular gypsum pseudomorphs. Macroquartz crystals in the pore filling are frequently observed at the macroscopical scale.

\section{TYPE 3}

This third type represents $10 \%$ of the studied assemblage. They are cherts with high potential for knapping and a heterogeneous texture. Macroscopically they display metal oxides, detrital quartz crystals, calcite or dolomite rhombohedral crystals and probably organic material as impurities. Sponge spicules and small foraminifera compose the micropalaeontological content.

\subsection{Original formations of the archaeological cherts from Forcas I Shelter}

Based on the fieldwork, it was found that the first identified group, those cherts which originated in a lacustrine sedimentary environment showed parallels with cherts which originated in the Oligocene micritic limestones that appear at the contact between the Ebro basin and the Pyrenean foothills. This type of chert is also similar to the lacustrine cherts from the Maastrichtian limestones that outcrop in the Carrodilla mountain range. Those formations have outcrops recovered at $20 \mathrm{~km}$ (Maastrichtian cherts) and $50 \mathrm{~km}$ (Oligocene cherts) from Forcas I Shelter.

The chert associated with a hypersaline environment has been connected to the Garumnian cherts that outcrop in the Carrodilla mountain range. In this case, outcrops are at $25 \mathrm{~km}$ from the archaeological site.

Finally, the third group defined, those marine cherts detected in the archaeological record, are related to cherts from the Conacian limestones (Agua-Salenz formation) which have outcrops at $25 \mathrm{~km}$ from Forcas I Shelter, near the Turbón Massif, and at $40 \mathrm{~km}$, in the Noguera Ribagorzana basin (Figure 7). 


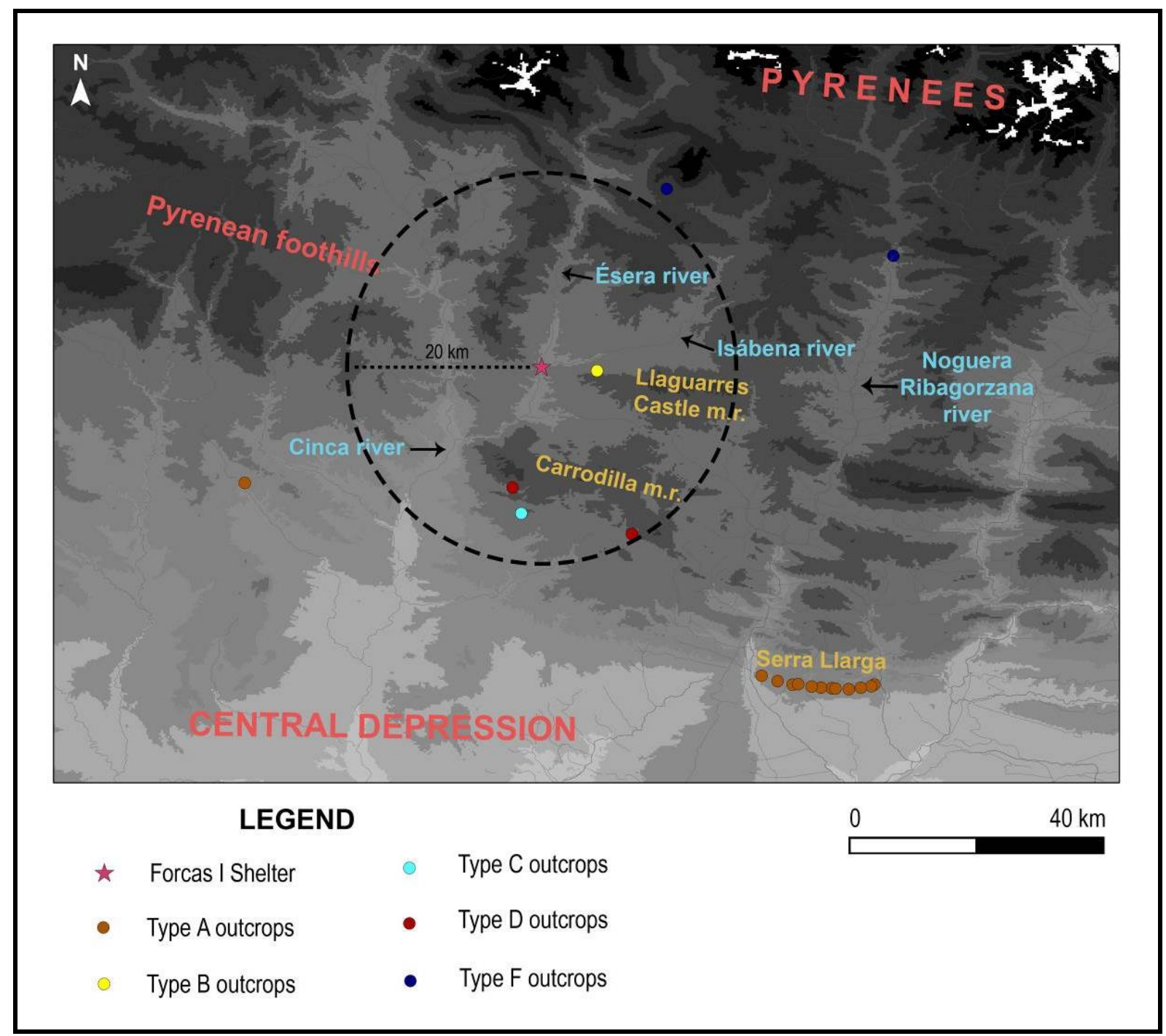

Figure 7. Forcas I Shelter and the different geological formations with parallels in the archaeological record.

\section{Contribution of the petroarchaeological study: detecting human mobility}

The petroarchaeological study of chert tools and remains collected in Alonsé Cave and Forcas I Shelter has allowed investigation into the lithic procurement strategies carried out by hunter-gatherer groups that settled in the Pyrenean foothills during the Cantabrian Lower Magdalenian. In this sense, after finding parallels between archaeological cherts and chert sources in the geological formations in the immediate environment, it is possible to infer the socioeconomic behaviour of these populations.

Firstly, lithic raw materials from Alonsé Cave have the same characteristics as cherts outcropping near the site, in the Garumnian, Campanian and Maastrichtian levels, found in a local procurement radius, which is less than $20 \mathrm{~km}$. In addition, there are similarities between some archaeological cherts and Oligocene cherts that outcrop in the contact with the Ebro basin, which is located just over $25 \mathrm{~km}$ from the site, in a regional procurement radius.

In the case of the $15 \mathrm{~b}$ level at Forcas I Shelter, the data analysed suggest two different supply areas. On the one hand, cherts delivered from a local procurement radius (less than 20 $\mathrm{km}$ ) are identified: Paleogene and Garumnian evaporitic cherts and Maastrichtian lacustrine cherts. On the other hand, cherts whose origin is in a regional radius (more than $20 \mathrm{~km}$, but less than $50 \mathrm{~km}$ ) are also characterized: Oligocene lacustrine cherts and Cenomanian marine 
cherts, whose outcrops are in the contact with the Ebro basin for the first case, and the Turbón massif and the Sopeira basin for the second type.

As a result of the petroarchaeological study, it is observed that lithic provisioning strategies carried out were similar in both assemblages, with the most used cherts being the ones originating from a lacustrine sedimentary environment, followed by the presence of hypersaline cherts from the Garumnian limestones that outcrop in the Carrodilla mountain range. However, some differences between both archaeological sets are also detected. On one hand, no transitional chert was found in level $15 \mathrm{~b}$ at Forcas I Shelter, being present only in a few specimens at Alonsé Cave. On the other hand, Coniacian marine cherts were only detected at Forcas I Shelter, and not at Alonsé Cave.

At this moment it is not possible to determine the reason for these differences because it is not known if both sites were exactly contemporaneous or whether several generations occurred between the occupations, which may have led the populations to pursue other procurement and management strategies.

The data presented in this paper is an approach to the notion of territory that the huntergatherers who occupied Alonsé Cave and Forcas I Shelter during the Cantabrian Lower Magdalenian could have had. Considering that the territory is conceived as the human appropriation of the geographical space, mainly due to the recognition and exploitation of its resources, it is understood that these Pyrenean foothills (mainly the Carrodilla and the Llaguarres Castle mountain ranges) and also the Cinca basin and its tributaries the Ésera and the Isábena rivers, should integrate the territory of these human groups. Therefore chert, as the main preserved resource at both sites, is an indicator of human appropriation of the geographical space.

The appropriation and exploitation of siliceous rocks from the Carrodilla mountain range marks the existence of a recurrent pattern of utilisation of the environment. Human groups that occupied both sites did not occupy these places by mistake. On the contrary, they had a good knowledge of the environment, which is revealed by the exploitation of lithic raw materials.

In view of understanding that Alonsé Cave and Forcas I Shelter served as stops along the mobility circuit of hunter-gatherer groups from the Upper Palaeolithic, cherts characterised as coming from a regional radius (Oligocene cherts from the contact with the Ebro Depression and Cenomanian cherts from the Turbón Massif and the Sopeira basin) may indicate previous stops and the circulation of such groups within this geographical space. Similarly, the appearance of these cherts in the archaeological record can be an indicator of the territory frequented by those communities.

Thus, if the different chert outcrops used at the sites studied are related, it suggests the idea of a primary route of circulation of materials and people (linking outcrops and archaeological sites) using waterways to avoid a steep topography. However, it has to be taken into account that some of these cherts that outcrop in the related formations may have arrived at more accessible places (secondary outcrops) where cherts which were detached from the bedrock were more suitable for knapping.

As a result, it can be concluded that groups who settled in Alonsé Cave and Forcas I Shelter during the Cantabrian Lower Magdalenian likely followed a mobility circuit. this circuit, from the Turbón massif, which is located in the Central Pyrenees or the upper basin of the Noguera Ribagorzana River axis (Cenomanian chert outcrops), could have pass through the Pyrenean foothills (Garumnian, Campanian and Maastrichtian chert outcrops) to reach the Central Depression (Oligocene chert outcrops). Following this route or the reverse direction, groups could move about according to economic, climatic and social conditions (Figure 8). 


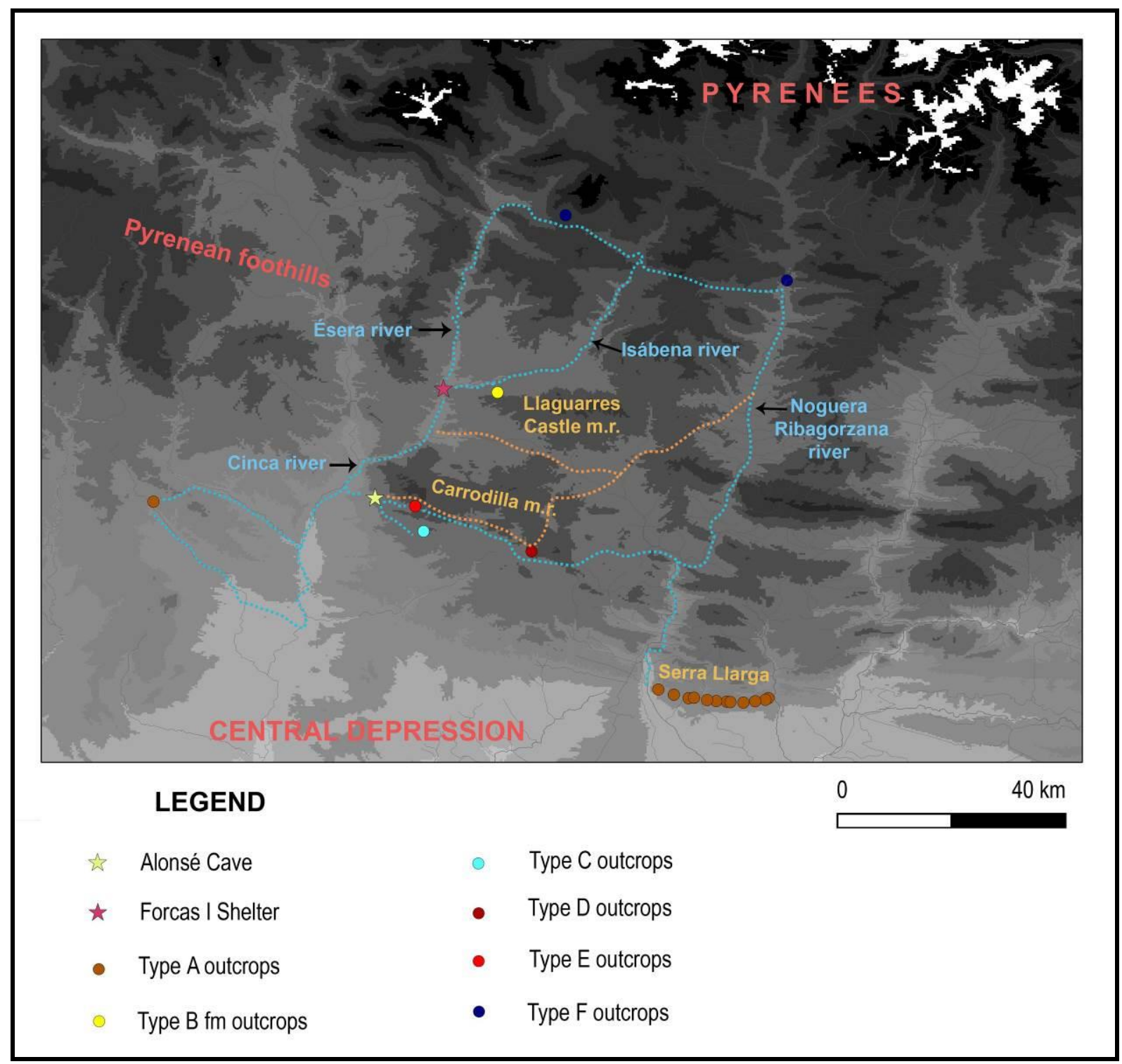

Figure 8. Alonsé Cave and Forcas I Shelter and the different geological formations with parallels in the archaeological record. In blue, most suitable routes to connect the chert outcrops with the archaeological sites taking into account the rivers axis. In brown, proposed route to avoid the narrow passes of the river and go directly to the sites.

\section{Conclusions}

The petroarchaeological study of chert elements collected at Alonsé Cave and Forcas I Shelter revealed interesting information about the management of siliceous rock resources employed by human groups at the end of the Upper Palaeolithic. This paper, however, is expected to be a preliminary approach to the study of chert tools, which should be complemented with the analysis of the entire assemblage of level 15b from Forcas I Shelter. It is also expected that the use of geochemical characterisation techniques will provide more accurate descriptions to complement the study done up to now.

In addition, the aim of the author is to relate the data presented here with other archaeological sites from the Central and Eastern Pyrenees that were occupied in the same period. The results obtained, will allow a more complete image of lithic procurement and management in the Central and Eastern Pyrenees during the Magdalenian period. 


\section{Acknowledgements}

The research presented in this paper was supported by an FPU grant from the Spanish Government and projects HAR 2011-26193 from the Spanish Government and SGR 200901145 from the Catalonia Government. I would like to thank Dr. Lourdes Montes and Dr. Pilar Utrilla for providing the archaeological materials from Alonsé Cave and Forcas I Shelter respectively, and to Dr. Xavier Mangado and Dr. Josep Maria Fullola for their constant help, interest and support.

\section{References}

Briois, F., 1997, Les industries lithiques en Languedoc méditerranéen (6000-2000 av JC). Rythmes et évolution dans la fabrication des outillages de pierre taillée néolithiques entre mer et continent, Ph.D Thesis at EHESS, Paris, 557 p. (in French) ("Lithic industries in Mediterranean Languedoc (6000-2000 BC). Rhythms and changes in manufacturing Neolithic carved stone tools between sea and continent")

Foucher, P., 2004, Les industries lithiques du complexe Gravettien-Solutréen dans les Pyrénées, Ph.D Thesis at University of Toulouse - Le Mirail, Toulouse, 334 p. (in French) ("Lithic industries from the Gravettian - Solutrean complex in the Pyrenees")

Grégoire, S., 2000, Origine des matières premières des industries lithiques du Paléolithique pyrénéen et méditerranéen. Contribution à la connaissance des aires de circulations humaines, Ph.D. Thesis at University of Perpignan, Perpignan, 246 p. (in French) ("Origin of raw materials origin from the lithic industries of the Pyrenean and Mediterranean Paleolithic. Contribution to the knowledge of human circulation")

Lacombe, S., 1998, Préhistoire des groupes culturels au Tardiglaciaire dans les Pyrénées centrales. Apports de la technologie lithique, Ph.D. thesis at University of Toulouse Le Mirail, Toulouse, 770 p. (in French) ("Cultural groups Prehistory in the Central Pyrenees during the Late Glacial Period. Contributions of lithic technology")

Mangado, X., 2004, L'arqueopetrologia del silex. Una clau per al coneixement paleoeconòmic $i$ social de les poblacions prehistòriques, Societat Catalana d'Arqueologia, Barcelona, 116 p. (in Catalan) ("The petroarchaeology of chert. A key to understanding the social and paleoeconomical knowledge of prehistoric groups")

Mangado, X., 2005, La caracterización y el aprovisionamiento de los recursos abióticos en la Prehistoria de Cataluña: las materias primas silíceas del Paleolítico Superior Final y el Epipaleolítico, BAR International Series Vol. 1420, Archaeopress, Oxford, 205 p. (in Spanish) ("Characterization and abiotic resource procurement in Prehistory of Catalonia: siliceous raw materials from the Final Upper Palaeolithic and the Mesolithic")

Menéndez, L., Rosell, J., Canals, A. \& Mosquera, M., 2009, El nivel G de las Fuentes de San Cristóbal (Huesca, España): Nuevas aportaciones al estudio del Paleolítico medio en el Pre-pirineo aragonés. Revista $C \& G, 23$ (1-2): 95-111. (in Spanish) ("Las Fuentes de San Cristóbal (Huesca, Spain) level G: new contributions to Middle Paleolithic in Aragon Pyrenean foothills")

Montes, L. \& Domingo, R., 2013, El asentamiento magdaleniense de Cova Alonsé, Monografías Arquelógicas Vol. 48, University of Zaragoza, Zaragoza, 154 p. (in Spanish) ("The Magdalenian settlement of Cova Alonsé (Estadilla, Huesca") 
Montes, L. \& Utrilla, P., 2008, Le Paléolithique Supérieur dans la moyenne vallée de l’Èbre. L'Anthropologie, 112 : 168-181. (in French) ("The Upper Palaeolithic in the Middle Ebro basin") doi:10.1016/i.anthro.2008.02.005

Normand, C., 2002, Les ressources en matières premières siliceuses dans la basse vallée de l'Adour et ses affluents. Quelques données sur leur utilisation au Paléolithique supérieur. In: Comportements techniques et économiques des sociétés du Paléolithique supérieur dans le contexte pyrénéen, (Cazals, N., Ed.), unpublished report, SRA MidiPyrénées: p. 26-38. (in French) ("Siliceous raw resources in the Adour lower valley and its tributaries. Some data on their use during the Upper Palaeolithic")

Ortega, D., 2002, Mobilitat i desplaçaments dels grups caçadors-recol-lectors a inicis del Paleolític superior a la regió pirinenca oriental. Cypsela, 14: 11-26. (in Catalan) ("Hunter-gatherer mobility and movement in the Eastern Pyrenees during the early Upper Palaeolithic")

Sáez, A., 1987, Estratigrafía y sedimentología de las formaciones lacustres del tránsito Eoceno - Oligoceno del NE de la Cuenca del Ebro, Ph.D. thesis at the University of Barcelona, Barcelona, 353 p. (in Spanish) ("Stratigraphy and sedimentology of the lacustrine formations from the Eocene - Oligocene transition in the northeast of the Ebro basin")

Sánchez, M. \& Mangado, X., 2013, La industria lítica de Cova Alonsé. Materias primas: tipos y aprovisionamiento. In: El asentamiento magdaleniense de Cova Alonsé (Estadilla, Huesca), Monografías Arquelógicas Vol. 48, (Montes, L. \& Domingo, R., Eds.), University of Zaragoza, Zaragoza: p. 41-53. (in Spanish) ("Lithic tools from Alonsé Cave. Raw materials: types and procurement")

Simonnet, R., 1999, De la Géologie à la Préhistoire: le silex des Prépyrénées. Résultats et réflexions sur les perspectives et les limites de l'étude des matières premières lithiques. Paléo, 11: 78-88. (in French) ("From Geology to Prehistory: Pyrenean foothills cherts. Results and reflections on the opportunities and limitations of the study of lithic raw materials")

Tarriño, A., 2006, El sílex en la Cuenca Vasco-Cantábrica y Pirineo Navarro.

Caracterización y su aprovechamiento en la Prehistoria, Monografías (Museo y Centro de Investigación de Altamira) Vol. 21, Ministerio Cultura, Madrid, 264 p. (in Spanish) ("Chert in the Cantabrian-Basque basin and the Navarrese Pyrenees. Characterisation and its use in Prehistory")

Terradas, X., 1996, La gestió dels recursos minerals entre les comunitats caçadoresrecol-lectores: vers una representació de les estratègies de proveïment de matèries primeres, Ph.D. thesis at the Autonomous University of Barcelona, Barcelona, 279 p. (in Catalan) ("Management of mineral resources between hunter-gatherer communities: toward a representation of raw material sourcing strategies")

Utrilla, P. \& Mazo, C., 2007, La Peña de Las Forcas de Graus (Huesca). Un asentamiento reiterado desde el Magdaleniense Inferior al Neolítico Antiguo. Saldvie, 7: 9-37. (in Spanish) ("The Peña de Las Forcas de Graus (Huesca). A repeated settlement from the Lower Magdalenian to the Ancient Neolithic")

Vera, J.A., 2004, Geología de España, Instituto Geológico y Minero Español, Madrid, 884 p. (in Spanish) ("Geology of Spain”) 
